\title{
Pola Asuh Si Kecil Di Era Digital Pada Masa New Normal
}

\author{
Andhi Dwi Nugroho" ${ }^{\# 1}$, Teguh Bangkit Pamungkas ${ }^{* 2}$, Hasna Zulfa Nurfauziah \#3, Titi Lestari ${ }^{* 4}$ \\ ${ }^{\# 1 * 4}$ Fakultas Keguruan dan Ilmu Pendidikan, Universitas Sarjanawiyata Tamasiswa, Yogyakarta \\ ${ }^{*}$ Direktorat Pascasarjana Pendidikan, Universitas Sarjanawiyata Tamansiswa, Yogyakarta \\ \#3 Fakultas Ekonomi, Universitas Sarjanawiyata Tamasiswa, Yogyakarta \\ 1andhidn@ustjogja.ac.id \\ bangkitpamungkasteguh@gmail.com \\ 3hasnazulfaur@gmail.com \\ ${ }^{4}$ titilestari@ustjogja.ac.id
}

\begin{abstract}
Abstrak: Kegiatan pengabdian ini bertujuan untuk menelaah pola asuh anak di era new normal dan mengetahui perlindungan dan pemenuhan hak-hak anak dalam pemberlakuan new normal di Indonesia. Data yang tersedia dihimpun dari sumber jurnal yang menjelaskan tentang isu terkait. Hasil pengabdian ini bertujuan untuk menunjukan upaya orang tua serta pemerintah dalam melindungi anak secara optimal di era new normal ini yaitu dengan cara: a) memberikan pengawasan anak dalam pengunaan gadget, b) menyediakan pulsa/internet, infrastruktur, dan fasilitas untuk proses pembelajaran daring, c) mengoptimalkan layanan pendidikan anak berbasis daring, d) mengoptimalkan layanan pendidikan anak desa, e) adanya kerjasama dalam melindungi anak antara pihak sekolah dengan orang tua.
\end{abstract}

Kata kunci: era digital, new normal, pola asuh si kecil

Abstract: This community service was aimed to analyse the parenting style in the new normal era and to reveal the protection and the need of children's rights in the implementation of new normal in Indonesia. The researcher collected the avalaible compiled data from journal sources that explain related issues. The result of this community service aims to point out the parents' and the government's effort in protecting children in this new normal optimally by the way of: a) giving supervision in using the gadget, b) providing internet data package, insfrastuctur, and facilities for online learning process, c) optimizing the online-based children education services, $d$ ) optimizing village children education services, e) cooperating to protect the children between school and parents.

Keywords: digital era, new normal, parenting style

\section{PENDAHULUAN}

Pandemi covid-19 menyebabkan anak-anak dan orang tua menjalani banyak waktu di rumah. Anak-anak menjalani belajar dan kehidupan dan kegiatan yang berbedabeda dan kegiatan tersebut dilakukan dirumah. Namun, tidak hanya anak-anak yang diminta untuk mengurangi aktivitas di luar rumah, akan tetapi semua orang diharapkan untuk tidak berada di kerumunan dan bahkan terdapat larangan mudik selama masa pandemi. Dengan demikian, peran penting orang tua di masa pendemi ini adalah menemani anak dalam belajar, beraktivitas dan berdoa yang semua kegiatan tersebut dilakukan di rumah. Hal tersebut tentu memberikan dampak pada perubahan pola kehidupan anak.

Kemajuan dalam bidang teknologi informasi dan komunikasi berkembang pesat selama beberapa dekade terakhir. Perkembangan tersebut tekah masuk dan 
memengaruhi semua aspek dalam kehidupan manusia. Di satu sisi, tidak hanya nilai positif yang diberikan oleh kemajuan era digital tetapi juga nilai konstruktif yang membuat banyak aktivitas manusia dan kebutuhan manusia lebih mudah dilakukan dan dipenuhi. Namun, di sisi lain, kemajuan tersebut tidak hanya akan membawa dampak negatif tetapi juga destruktif/merusak apabila sikap kritis dan selektif tidak dimiliki oleh manusia.

Herminanto dan Wirnarno (2012: 161) mengatakan bahwa kemajuan dalam bidang teknologi informasi dan komunikasi telah mempengaruhi kehidupan anak terutama oleh penggunaan perangkat digital. Dengan kata lain, teknologi digital di era milenial sangat memengaruhi kehidupan anak-anak. Bahkan, sebutan digital native disematkan kepada anak-anak di era ini karena mereka sudah mengetahui perangkat elektronik maupun digital sejak lahir (Kemendikbud RI, Juli 2016).

Peran orang tua dalam meningkatkan pola asuh anak di era milenial harus sesuai dengan karakteristik, sikap, dan perilaku anak-anak di era ini yang ditunjukkan oleh semakin kuatnya penggunaan perangkat digital. Hal tersebut ditujukan supaya terhindar dari pengaruh buruk dan dapat menggunakan perangkat tersebut secara bijaksana untuk kegiatan yang bermanfaat.

Pola asuh memiliki pola interaksi antara orang tua dengan anak. Pola interaksi ini meliputi perilaku maupun sikap orang tua saat berhubungan dengan anak. Menurut Baumrind Berk (1994) terdapat 3 pola asuh orang tua antara lain otoriter, demokrasi, dan permisif. Akan tetapi, seiring dengan perkembangan zaman, pola asuh dapat tidak hanya mengacu pada tiga pola asuh yang telah dijelaskan sebelumnya tetapi juga pola asuh lainnya karena mengalami perubahan dan mengikuti perkembangan zaman tersebut.

Pola asuh seperti ini harus ditetapkan orang tua pada usia dini supaya anak-anak ketika beranjak dewasa memiliki sikap kritis dan selektif dalam setiap kemajuan. Menurut Santosa (2015: 104), pola asuh anak yang efektif tidak hanya mendidik anak saja, tetapi berkaitan dengan karakter dan mentalitas anak. Di tengah pademi covid-19 ini, peran orang tua sebagai pendidik juga berupaya untuk mempersiapkan anak untuk menghadapi era digital saat ini. Oleh karena itu, orang tua mempunyai peran dalam mengimplementasi pola asuh anak yang baik dan efektif yang diterapkan pada tumbuh kembang anak karena orang tua adalah pendidik pertama sehingga peran keluarga harus terlibat dalam pendidikan anak yaitu dengan berbentuk pengasuhan yang baik. Dalam hal ini, orang tua diminta untuk mendampingi dan membimbing anak pada semua tahapan tumbuh kembangnya dengan 
memenuhi kebutuhan anak tidak hanya dalam segi fisik tetapi juga psikis.

Pada masa pandemi ini, orang tua diharapkan dapat berperan sebagai pembimbing, pengajar, dan pengawas pada kegiatan serta tumbuh anak, apalagi dengan mayoritas kegiatan anak dilakukan dirumah baik itu kegiatan sekolah maupun aktivitasnya. Meskipun harus ada penyesuaian atas kebijakan pembelajaran di masa pademi covid-19 baik itu kendala dari pihak sekolah, pihak oragtua bahkan dari siswa. Seiring berkembangnya teknologi dan informasi dan internet, pembelajaran dilakukan secara online. Maka akhir-akhir ini muncul banyak istilah dimasyarakat seperti $e$ learning/daring/online yang dimakud yaitu pembelajaran yang menggunakan platform atau perangkat elektronik yang disambungkan dengan jaringan internet. Menurut Johnson dan Manning (2010) mengatakan bahwa Pendidikan secara daring merupakan bentuk pembelajaran yang menghubungkan siswa dan materi pembelajaran melalui jaringan internet. Hal ini didukuang oleh kebijakan pendidikan yang termuat dalam Surat Edaran Kementrian Pendidikan dan Kebudayaan nomor 3 dan 4. Tilaar dan Nugroho (2009: 264) mengatakan bahwa kebijakan pendidikan adalah kebijakan yang dibuat untuk publik dalam bidang Pendidikan. Kebijakan tersebut diharapkan pemerintah sebagai alat yang ditujukan untuk membawa perubahan yang positif. (Madjid, 2018: 12-13). Kebijakan publik tersebut ditetapkan karena penyelenggaraan pendidikan pada masa pandemi ini tidak bisa dilaksanaakan secara tatap muka yang menimbulkan adanya kebijakan baru supaya tujuan yang diinginkan dapat tercapai. Peraturan Pemerintah Pengganti Undang-Undang dan Peraturan Pemerintah terkait penangan covid-19 adalah dua kebijakan publik yang dibuat oleh Menteri Pendidikan dan Kebudayaan.

Masalah utama munculnya kebijakan e-learning dalam proses pembelajaran yang menyebabkan kekhawatiran berkembang serta menyebarnya covid-19 di lingkungan satuan pendidikan karena virus ini sudah menyebar di masyarakat. Adanya kebijakan e-learning mengharuskan orang tua untuk mengawasi pada saat melakuan pembelajaran dengan virtual. Dengan demikian, menurut Madjid (2018: 17), kebijakan tersebut sudah mencukupi syarat sebagai unsur masalah. Sugiyono (2017: 6) mengatakan bahwa kebijakan ini telah mencukupi syarat sebagai rumusan masalah yang ilmiah dan jelas berdasarkan data yang akurat, lengkap, dan terkini karena kebijakan tersebut dikeluarkan setelah mengamati terus bertambahnya pasien covid-19 di masyarakat dan memperhatikan ketersedian akses internet di sekolah. Tujuan adanya kebijakan e-learning 
yaitu sebagai perlindungan masyarakat dari paparan infeksi covid-19 dan jaminan pelaksanaan pembelajaran secara e-learning.

Di Indonesia, rata-rata anak menggunakan waktu mereka untuk menonton siaran sehari-hari lebih dari satu jam untuk menonton siaran televisi dengan rata-rata $(54,4 \%)$, memutar video (30\%), mengoperasikan computer selama $(32,5 \%)$, dan $(67,3 \%)$ untuk bermain game elektronik (Febriana, 2016). Maka dari itu, peran orang tua dalam pengawasan perilaku anak anak sehari hari harus lebih protektif dan dapat melakukan pengontrolan dengan baik terutama dalam pengunakan alat elektronik yang di masa pandemi Covid-19 ini yang pembelajarannya berbasis online. Penggunaan internet yang terus menerus dapat menimbulkan dampak positif dan dampak negatif untuk penggunanya termasuk juga anak-anak. Jika hal tersebut tidak dikelola dengan baik, maka di sebagian besar kehidupan sehari-harinya mereka anak selalu menggunakan internet. Disamping itu, tidak hanya dampak positif yang didapat, tetapi juga ada efek negatif yang perlu ditanggulangi secara serius.

Di era new normal, perlindungan anak adalah bentuk dari pola asuh anak hal yang harus sangat diperhatikan. Pelindungan anak tersebut harus diupayakan dan dimulai sedini mungkin supaya kelak dapat memberi andil dalam pembangunan bangsa dan negara secara optimal. Pasal 2 ayat 3 dan 4 Undang Undang Nomor 4 Tahun 1979 tentang Kesejahteraan Anak, ditentukan bahwa: anak berhak atas pemeliharaan dan perlindungan, baik semasa dalam kandungan maupun sesudag dilahirkan baik atas perlindungan dari lingkungan. Apabila dikaitkan dengan tujuan adanya perlindungan dan pemenuhan hak anak di masa new normal ini, masyarakat perlu waspada terhadap angka kasus pademi pada anak. Pada tanggal 25 Mei 2020, jumlah anak dengan usia 0 - 17 tahun yang terpapar Covid-19 yaitu pasien dalam pengawasan sebanyak (PDP) sebanyak 3.324 kasus, 129 anak berstatus PDP meninggal dunia, 548 kasus tekonfirmasi positif dan 14 meninggal dunia akibat covid-19. Data tersebut berasal dari Ketua Umum Pengurus Pusat Ikatan Dokter Anak Indonesia (IDAI). Tingginya angka kasus menjadi perhatian Kemen PPA. Pada masa new normal ini, Kemen PPA menginginkan perlindungan anak dari penularan covid-19 dijamin oleh negara karena dalam masa ini akan terjadi perubahan pada semua aspek kehidupan. Maka dari itu, dalam menghadapi era new normal ini dibutuhkan peran keluarga dan lingkungan sosial masyarakat yang solid.

Upaya perlindungan terhadap anak untuk melindungi dari covid-19 adalah dengan menerapkan langkah-langkah preventif dalam melakukan kegitan seharihari seperti membatasi kontak antar anggota 
masyarakat. Upaya yang ditujukan untuk melindungi diri sendiri dan orang lain tersebut juga dikenal sebagai Sosial Distancing/ Physical Distancing.

\section{RUMUSAN MASALAH}

Kegiatan pengabdian kepada masyarakat ini bertujuan untuk menelaah pola asuh anak di era new normal dan mengetahui perlindungan dan pemenuhan hak-hak anak dalam pemberlakuan new normal di Indonesia.

\section{METODE}

Kegiatan pengabdian kepada masyarakat dilaksanakan menggunakan metode praktik, simulasi, dan transfer ilmu yang didukung dengan studi literatur. Data yang tersedia dihimpun dari kegiatan di lapangan dan jurnal pengabdian yang menjelaskan tentang isu terkait.

\section{HASIL PEMBAHASAN}

Pola asuh di era digital sangat penting untuk dipahami dan dilakukan tidak hanya dari pihak orang tua saja di rumah tetapi juga guru di sekolah. Perkembangan teknologi digital yang begitu masif membuat siswa yang masih dalam tahap operasional tetapi sudah mampu mencari dan mengkaji berbagai macam informasi lebih cepat daripada guru dan orang tua mereka. Kecepatan dan kemudahan dalam mengakses internet seharusnya perlu pengawalan, pengawasan, dan pengamatan agar anak tidak melakukan penyelewengan, salah arah, dan pelanggaran dalam pengunaan internet terutama gadget. Upaya orang tua terhadap pencegahan ketergantungan, pelanggaran, dan penyelewengan perlu dilakukan.

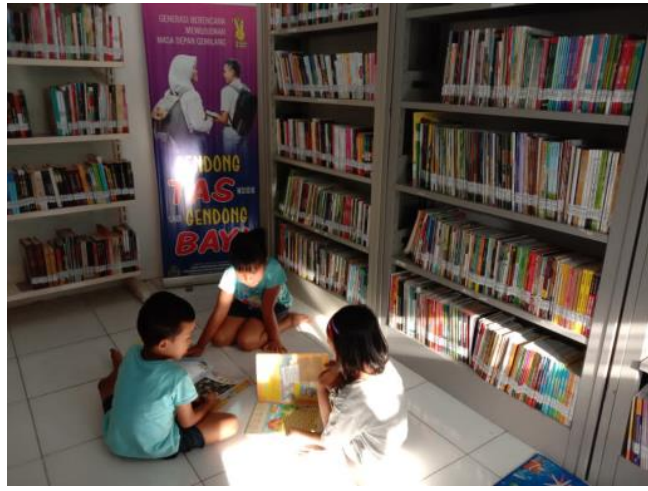

Sumber : Perpustakaan Desa Ngawu

Pada zaman milenial ini, pandangan orang terhadap banyak hal yang ada di kehidupan sehari-harinya khususnya dalam hal menjadi orang tua telah dipengaruhi oleh kemajuan teknologi komunikasi dan informasi. Misalnya, dahulu anak-anak dibiarkan untuk bermain dolanan tradisional bersama anak-anak di luar rumah. Namun, pada era digital ini, permainan menggunakan teknologi digital lebih diandalkan oleh banyak orang tua. Banyak orang tua yang kemudia berlomba-lomba memberikan akses teknologi digital pada anak anak mereka tanpa memikirkan efek yang akan diperoleh. 


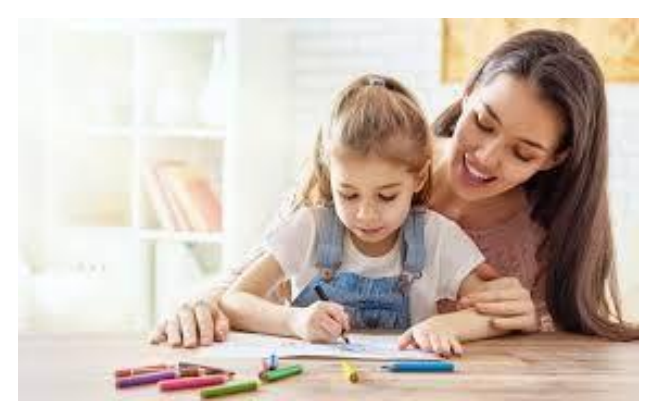

Sumber : https://www.kompasiana.com/niss aull/5da19d0d097f361ec867ef64/15-gayapola-asuh-anak-yang-perlu-anda-ketahui

Interaksi antar manusia dengan manusia mulai terkikis dengan adanya teknologi. Bahkan, secara langsung interaksi dengan orang-orang di sekitar tempat tinggal juga berkurang dengan tidak disadari. Dapat diilustrasikan hal tersebut terjadi di antara hubungan orang tua dan anak dirumah yang sibuk dengan gadget mereka masing-masing padahal gadget bukan merupakan kebutuhan primer.

Kemajuan dan kemudahan dalam penggunaan teknologi membuat anak-anak yang masih berusia dini sudah mampu mengoperasikan teknologi digital seperti gawai. Dengan adanya teknologi mampu menghadirkan stimulus suara dan visual disaat bersamaan membuat abak mampu untuk mempelajari banyak hal dalam satu waktu. Misalnya, perkembangan teknologi yang pesat memunculkan teknologi digital yang disamping mempunyai banyak fungsi tetapi juga harga yang terjangkau bagi masyarakat. Hal tersebut mengakibatkan masyarakat mudah untuk memilikinya.
Bahkan, dalam keluarga tertentu gadget telah dimiliki oleh anak balita hingga anak usia sekolah mulai SD, SMP, dan SMA.

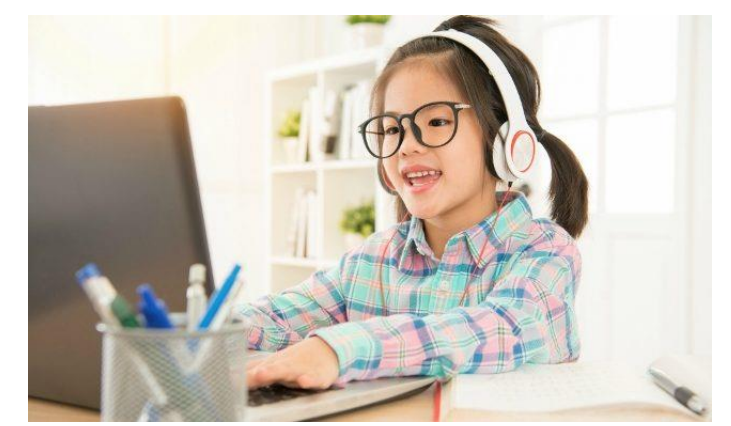

Sumber :https://www.kalderanews.com/202

0/08/penyebaran-covid-19-pada-anak-

begini-catatan-ikatan-dokter-anak/

Pada akhirnya, teknologi sudah banyak diberikan oleh orang tua. Tanpa disadari anak mulai ketergantungan dalam pemakaian gadget karena teknologi sudah mulai banyak diberikan kepada anak. Mungkin untuk sebagian itu dianggap sepele oleh mereka. Mereka juga beranggapan bahwa era digital yaitu memakai gadget tanpa memikirkan dampak yang akan didapat sang anak. Tanggung jawab harus dimiliki orang tua dalam membentuk karakter anak.

Peran orang tua dalam memberikan pemahaman terhadap anaknya dimaksudkan supaya menjadi pengalaman dan pemahaman sebelum mereka membaur di sekolah dan masyarakat. Oleh karena itu, keteladanan orang tua sangat berperan penting bagi perkembangan anak mereka. Hal ini penting karena lingkungan sekitar anak sangat berpengaruh terhadap tahap perkembangan manusia dan usia anak karena dalam tahap ini 
anak akan mencontoh perilaku di sekitar lingkungan tersebut. Oleh karena itu, pola asuh yang sesuai dengan kehidupan anak diperlukan orang tua dalam mendidik anak.

Berbagai macam kegiatan yang dapat dilakukan orang tua sebagai pendidikan karakter anak. Orang tua secara aktif melakukan pengawasan dan memantau perkembangan perilaku anak mereka melalui kegiatan rutin meskipun sekarang seluruh aktivitas anak dilakukan di rumah. Era digital saat ini anak-anak tidak lepas dari gadget sebagai kebutuhan. Orang tua juga mempunyai peran dalam membatasi dan mengawasi anak dalam menggunakan teknoloi digital, mengatur waktu kapan ia mengerjakan tugas sekolah, mengatur kapan dia bersosialisasi dengan teman bahkan dengan keluarganya. Pada era digital ini, jarang sekali anak yang terlihat bermain dengan permainan tradisional namun mereka banyak berinteraksi dengan teknologi. Peran penanaman karakter dalam bidang pendidikan antara lain:

1. Pembinaan watak merupakan tugas dari Pendidikan

2. Secara bertahap, kebiasaan buruk diubah menjadi baik. Mampu mengubah kebiasaan senang tetapi tidak baik menjadi kebiasaan yang baik kemudian menjadikan yang kebiasaan jelek tersebut akhirnya tidak disukai.
3. Sikap, perbuatan, dan tindakan dapat dengan mudah dan spontan muncul dan dipancarkan oleh seseorang karena sebagai hasil dari karakter yang ada di dalam jiwanya.

4. Karakter merupakan wujud kemampuan seseorang untuk menunjukkan perilaku terpuji dan mengandung kebajikan yang didorong dari dalam dirinya.

Nilai jujur, tanggung jawab, disiplin, sehat, bersih, dan peduli antar sesama merupakan nilai yang harus dibangun di sekolah. Namun, dengan adanya pademi covid-19 peran sekolah untuk menanamkan karakter pada anak menjadi tanggung jawab orang tua namun tidak hanya sepenuhnya orang tua saja tetapi juga perlu adanya motivasi dari guru.

KPAI menilai bahwa waktu bersama antara orang tua dan anak menjadi lebih berharga karena kualtias waktu sehari-hari dihabiskan bersama dengan seluruh anggotanya. Aktivitas keluarga yang terpusat dirumah. Peran orang tua melakukan pengawasan full pada anak meskipun orang tua menjadi pusat aktivitas keeluarga yang selama ini terpecah pecah baik dari pekerjaan kantor, sekolah, rumah ibadah hingga lingkungan masyarakat.

Menurut Rita Pranawati, MA selaku Wakil KPAI menjelaskan bahwa dengan adanya pademi covid-19 orang tua dapat mengajarkan pola hidup bersih dan sehat. 
Orang tua dapat memulai kebiasaan dari cuci tangan yang benar, menganti baju dan mandi setelah berpergian. Selain itu, membiasakan pola makan yang sehat dan gizi seimbang dan jika bersin lakukanlah dengan cara yang benar. Orang tua juga mengedukasi kepada anak tentang kondisi pademi covid-19 supaya anak tidak merasa panic dan tetap tenang. Namun untuk kebijakan tatanan normal (new normal) ditengah pademi Covid-19, mengharuskan para orang tua dan keluarga di seluruh nusantara untuk memberikan pengasuhan bagi anak yang sesuai dengan kondisi yang terjadi saat ini. Orang tua perlu sekreatif mungkin menjaga situasi kondusif di rumah agar anak-anak nyaman di rumah meskipun kebijakan new normal ditengah pademi ini akan diterapkan.

Lenny dari Kementrian PPA menjelaskan bahwa penerapan pola asuh anak harus berdasarkan perlindungan anak yaitu dengan pemenuhan hak anak dan perlindungan khusus anak baik pada masa sebelum pandemi, saat pandemi, maupun new normal (Susanti, 2018). Hal ini bertujuan untuk pemenuhan atas kelekatan, kasih sayang, keselamatan dan kesejahteraan yang menetap dan berkelanjutan demi memberikan hal yang terbaik kepada anak. Menurutnya, penyesuaian dengan kondisi yang ada sangat diperlukan pada pola asuh anak di masa pandemi ini. Peran orang tua dalam pola asuh tersebut yaitu sebagai pengasuh, pendamping dan sekaligus teman bicara anak anak selama 24 jam dan harus menyesuaikan kembali dengan perubahan yang ada

Berikut ini penjelasan Lenny yang harus diingatkan orang tua kepada anak saat bersekolah pada masa new normal:

a. Tidak melepas masker selama disekolah

b. Mematuhi aturan jarak yang aman pada saat menggunakan transportasi umum.

c. Tidak menyentuh apapun di dalam transportasi umum.

d. Tangan segera dicuci ketika sudah sampai di tempat tujuan.

e. Mematuhi aturan jarak aman dengan orang lain seperti dengan teman, guru dan warga sekolah.

f. Hanya memakan bekal yang dibawa dari rumah.

g. Segera mengganti pakaiannya sesampai dirumah.

h. Rajin mencuci tangan dengan sabun.

Ketua Himpunan Psikologi Indonesia, Seger Handoyo menyampaikan bahwa peran orang tua yang utama dalam Pola Asuh anak adalah membantu anak dalam memperkuat mental psikologi anak supaya lebih optimis, termotivasi untuk meraih cita-cita, santai, tidak mudah cemas dan mempu menghadapi masalah. Berikut ini tips-tips yang bisa dilakukan orang tua untuk mempersiapkan anak kembali bersekolah (Dikutip dari Halodoc.com) antara lain: 
1. Menjelaskan pada anak tentang perubahan pada kondisi sekolah.

Langkah pertama yang bisa orang tua lakukan untuk mempersiapkan anak kembali ke sekolah adalah dengan menjelaskan perubahan yang akan terjadi di sekolah. Bicarakanlah pada anak bahwa mungkin terjadi perubahan pada beberapa hal yang ada di sekolah, karena para guru telah memikirkan cara untuk membuat kegiatan belajarmengajar tetap aman. Perubahan yang mungkin akan dibuat di sekolah, antara lain:

a. Tata letak kursi di ruang kelas yang dibuat berjarak

b. Bila sekolah menyediakan foto ruang kelas yang baru, perlihatkan pada anak, sehingga mereka tahu seperti apa tata ruang kelas yang baru.

c. Jam mulai dan selesai sekolah yang berbeda.

d. Diajar oleh guru yang berbeda.

2. Membicarakan tentang protokol Kesehatan

Selain perubahan pada kondisi sekolah, orang tua juga perlu memberi gambaran pada anak seperti apa beraktivitas atau bersekolah kembali pada masa pandemic ini. Jelaskanlah padanya bahwa di masa new normal ini, anak dapat belajar kembali di sekolah seperti biasa, tetapi bukan berarti virus corona sudah menghilang sepenuhnya

3. Kebiasaan ke Rutinitas

Waktu tidur dan bangun anak mungkin sudah berubah sejak masa karantina di rumah. Karena itu, cobalah untuk mulai membiasakan anak secara bertahap untuk kembali ke rutinitas sekolah seperti dulu. Orang tua bisa melatih anak untuk disiplin, mulai dari tidur awal, bangun pagi, menyiapkan keperluan sekolah, dan lain-lain.

4. Tidak usah cemas secara berlebihan.

Pada kondisi pademi ini, tentunya wajar jika orang tua akan merasa cemas untuk melepas anaknya kembali ke sekolah. Akan tetapi, overprotektif yang ditandai dengan kecemeasan berlebihan tersebut akan membuat anak merasa tidak nyaman. Hal tersebut juga memengaruhi dan membuatnya merasa cemas pada saat kembali ke sekolah. Karena itu, sebisa mungkin jangan terlalu cemas, melainkan persiapkan anak sebaik mungkin agar ia dapat beradaptasi dan tetap waspada ketika disekolah

Seiring dengan berjalannya waktu, Covid-19 menyebar pesat ke seluruh penjuru dunia. Kondisi tersebut menyebabkan wabah tersebut ditetapkan oleh Organisasi Kesehatan Dunia (WHO) sebagai pandemic global. Lalu, istilah Herd Immunity muncul 
dalam dunia kesehatan yang mengandung arti perlindungan diri atau imunitas tubuh. Untuk menyederhanakan pemahaman kita tentang new normal, Ketua Tim Pakar Gugus Tugas Percepatan Covid-19 menyatakan bahwa new normal merupakan sikap atau perilaku untuk selalu menerapkan protocol kesehatan dalam menjalankan segala aktivitas normal guna sebagai pencegahan penyebaran covid-19. Beradaptasi dengan pola hidup yang baru merupakan prinsip utama dalam new normal.

\section{SIMPULAN}

Pola asuh anak bertujuan untuk membentuk tindakan yang dinilai positif dan efektif dalam membentuk karakter anak. Di masa pandemi ini, pengaruh dalam penggunaan peralatan digital oleh anak harus dikendalikan dengan baik dan benar oleh orang tua dengan cara melakukan pengawasan yang protektif sejak dari keluarga. Pola asuh yang bersifat bijaksana, membangun, positif dan kreatif pun dapat diterapkan oleh orang tua dalam mendidik anaknya. Pola asuh perlu dibagun dalam diri orang tua dan dilatih terus menerus, sehingga para orang tua menjadi sosok teladan yang diinginkan anak anaknya

Selain itu, pada penerapan kebijakan new normal ini, persiapan orang tua dinilai sangat penting. Maka dari itu, penyesuaian pola asuh anak yang diberikan oleh orang tua harus disesuaikan dengan kondisi pada masa new normal. Mental anak perlu disesuaikan dengan keadaan dimana harus tetap mengikuti protokoler kesehatan dan melakukan anjuran anjuran yang harus dilakukan sang anak ketika kembali untuk bersekolah. Bukan berarti dengan adanya kebijakan new normal pademi ini berakhir namun dengan adanya kebijakan ini kita harus tetap produktivitas meskipun pademi ini belum berakhir.

Organisasi Kesehatan Dunia (WHO) meyampaikan bahwa pada saat memasuki era new normal pada masa pandemi, upaya perlindungan dan pemenuhan kebutuhan hak anak adalah dengan menerapkan new normal yaitu melakukan perubahan perilaku dalam menjalankan aktivitas sehari-hari dengan menambahkan protokol kesehatan yang sesuai dengan anjuran pemerintah. Anjuran tersebut diharapkan sebagai bentuk untuk mencegah penularan covid-19 dan memperkuat hubungan di dalam keluarga seperti kasih saying, keselamatan, kesejahteraan, dan kelekatan yang berfokus pada kepentingan si kecil.

\section{DAFTAR PUSTAKA}

15 Gaya Pola Asuh Anak yang Perlu Anda Ketahui. Kompasiana.com. Diakses melalui

https://www.kompasiana.com/nissaull/ 5da19d0d097f361ec867ef64/15-gayapola-asuh-anak-yang-perlu-andaketahui (Diakses 11 September 2020) 
Berk, L. E. Child development t. (3rd ed). 1994. Boston : Iallyn and Bacon

Budi Winarno. 2012. Kebijakan Publik: Teori, Proses, dan Studi Kasus. Yogyakarta: CAPS.

Febriana, L. P. 2016. Peran Orang Tua Terhadap Keputusan Memilih Tayangan untuk Anak. Banten: Universitas Sultan Ageng Tirtayasa.

HAR Tilaar \& , Riant Nugroho. Kekuasaan dan Pendidikan. 2009. Jakarta: Rineka Cipta.

Johnson, K. dan Manning, S. Online Education for Dummies. 2010. Canada: John Wiley \& Sons Publishing. ISBN 0470536209.

Kemendikbud. Permendikbud Nomor 22 Tahun 2016 Tentang Standar Proses Pendidikan Dan Menengah. 2016. Jakarta: Kemendikbud.

Kementerian PPPA: Pengasuhan Anak di Era New normal Perlu Pedoma. Kompas.com. Diakses Melalui https://nasional.kompas.com/read/202 0/06/03/13484011/kementerian-pppapengasuhan-anak-di-era-new-normalperlu-pedoman. (Diunduh pada 2 September 2020)

Madjid, A. B. D. Analisis Kebijakan Pendidikan. 2018. Yogyakarta: Samudra Biru.

Penyebaran Covid-19 pada Anak, Begini Catatan Ikatan Dokter Anak. Kaldera News. Diakses melalui http://www.kalderanews.com/2020/08/ penyebaran-covid-19-pada-anakbegini-catatan-ikatan-dokter-anak/ (Diakses 11 September 2020)

Santosa, Elizabeth T. Raising Children In Digital Era (Pola Asuh Efektif untuk Anak di Era Digital). 2015. Jakarta: PT Elex Media Komputindo.

Sugiyono. Metode Penelitian Kuantitatif, Kualitatif, dan R\&D. 2017. Bandung: Alfabeta, CV.

Susanti, E. K. 2018. Pola Asuh Pengasuh Terhadap Pembentukan Kepribadian Anak di Rumah Kreasi Edukasi Waya Halim Bandar Lampung. Lampung:
Universitas Agama Islam Negri Raden Intan.

Tips Mempersiapkan Anak Kembali Ke Era New normal. Hallodoc. Diakses melalui

https://www.halodoc.com/artikel/tipsmempersiapkan-anak-kembali-kesekolah-di-era-new-normal. (Diakses 11 September 2020) 